\title{
Role Of Prosecutor General Prosecution Of Actors In The Implementation Of Abuse Of Narcotics Crime (Case Study in Magelang District Attorney)
}

\author{
Arif Hidayat $^{1}$ and Sri Endah Wahyuningsih ${ }^{2}$
}

\begin{abstract}
Prosecutor as one of the law enforcement agencies in Indonesia have a role in the prosecution, it is stipulated in Article 2 (1) of the Constitution of the Republic of Indonesia Number 16 of 2004 on the Prosecutor of the Republic of Indonesia. Prosecution is the act of the General Prosecutor for criminal matters delegated authority to the District Court in the case and in the manner set forth in the criminal procedure law to demand that tried and sentenced by the judge at the hearing. Drug abusers are people who use narcotics without authority or unlawfully. This study uses empirical juridical approach with descriptive analytical research specifications, types and sources of data are the primary data by conducting interviews and secondary data by performing a literature study, data analysis method logically and systematically. The results showed that the procedure includes the step prapenuntutan prosecution, prosecution and execution. The role of the public prosecutor in the criminal case handling drug abuse is a public prosecutor. Factors inhibiting the role of the public prosecutor in the prosecution that the case file is not yet complete, the type of drug is not on the list of narcotics, modus operandi vary and calling witnesses when the examination before the court, while the effort to overcome that by making the sharing of information between law enforcement, conduct legal counseling, attended a special training program narcotic crime and Attorney for School.

Keywords: Role; Prosecution; Narcotics Abusers.
\end{abstract}

\section{Introduction}

Indonesia is a country of law ${ }^{3}$, Affirmation of this constitutional provision means that all aspects of life in the community, state and government should always based on the law. That the philosophical foundation of the birth of the Law of the Republic of Indonesia Number 35 of 2009 on Narcotics contained in the preamble of point (b): "that in order to improve the health of Indonesian human resources in order to realize the people's welfare is necessary to the improvement in the field of medical and health services, among others by ensuring the availability of certain types Narcotics badly

\footnotetext{
${ }^{1}$ Student of Masters (S2) of Law Faculty of Law Unissula email arif_hidayat_1985@yahoo.co.id

2 Lecturer of Faculty of Law UNISSULA Semarang

${ }^{3}$ Article 1 (3) of the Constitution of the Republic of Indonesia Of 1945 a third amendment.
} 
needed drugs and the prevention and eradication danger of abuse and illicit traffic of Narcotics and Narcotics Precursor " 4 ,

Narcotics are substances or drugs that are beneficial and necessary for the treatment. However, if abused can lead to very adverse consequences. It would be detrimental if it is accompanied by the illicit trafficking that could result in a greater danger to the life and cultural values of the nation that will ultimately weaken national security. ${ }^{5}$

Narcotics problems can generally be divided into three (3) inter-related parts, namely the production of illegal drugs (drug illkit production), the illicit trade in narcotics (illkit traffikking) and their abuse of drugs (drug abuse). ${ }^{6}$

The problem of drug abuse is a complex issue, requiring a comprehensive prevention efforts involve working with a multidisciplinary, multisectoral, and active community participation. The rise of drug abuse not only in big cities, but it has reached small towns including Magelang. One component of law enforcement in Indonesia is the Prosecutor (hereinafter referred to Attorney General), in which the role of the Prosecutor's one of them is in the prosecution of crime.

In 2017, according to data recorded in the State Attorney Magelang District, there are 32 (thirty-two) cases of criminal acts of abuse of narcotic by the number of perpetrators of 33 (thirty-three). This data is greater than in 2016, amounting to 29 (twenty nine) cases of criminal acts of drug abuse by the perpetrator as much as 29 (twenty nine). ${ }^{7}$

Based on the above background, the authors are interested in doing research with the title, "Role Of Prosecutor General Prosecution Of Actors In The Implementation Of Abuse Of Narcotics Crime (Case Study in Magelang District Attorney)" and the formulation of the problem, namely: What is the procedure for prosecution of perpetrators of criminal acts of drug abuse?; How is the role of the public prosecutor in the implementation of the criminal prosecution of drug abuse?; What are the factors inhibiting the role of the public prosecutor in the implementation of the criminal prosecution of drug abuse and how attempts to solve it?

\section{Research Methods}

In this research, the writer used juridical empirical approach. Empirical juridical include research into the identification of law (common law) and research on the effectiveness of the law. ${ }^{8}$

\footnotetext{
${ }^{4}$ The preamble section (Considering) point b Law of the Republic of Indonesia Number 35 of 2009 on Narcotics.

${ }^{5}$ General Explanation of the Law of the Republic of Indonesia Number 35 of 2009 on Narcotics.

${ }^{6}$ Erwin Mappaseng 2009 Pemberantasan dan Pencegahan Narkoba yang Dilakukan oleh Polri dalam Aspek Hukum dan Pelaksanaannya Buana Ilmu Surakarta p. 2.

${ }^{7}$ Data Case Narcotics Crime in 2016 and 2017 in Magelang District Magelang District Attorney March 19 2018.

${ }^{8}$ Dyah Ochtorina Susanti dan A'an Efendi 2014 Penelitian Hukum (Legal Research), Sinar Grafika Jakarta p. 18.
} 
The research is descriptive analytical specifications, which describe the legislation in force associated with the theories of law and positive law enforcement practice concerning these issues.

While the types and sources of data that isThe primary data obtained directly from the source or the respondent. ${ }^{9}$ The primary data obtained by conducting direct interviews with sources. In addition to the primary data is also used secondary data obtained indirectly. Secondary data were obtained by conducting the study of literature in the form of books, legislation, and documents.

While the method of data analysis that is logically and systematically. Systematic logical inductive means showing the way of thinking and follow the procedures in the writing of a scientific research report. Once the data analysis is complete, the results will be presented descriptively, by describing what their role in the implementation of the Public Prosecutor for prosecution of perpetrators of criminal acts in accordance with the problems of drug abuse is being investigated. ${ }^{10}$

\section{Results And Discussion}

\subsection{Prosecution Procedures Against Crime Perpetrators of Abuse of Narcotics}

Prosecution of criminal abuse of narcotics in the State Attorney Magelang them on case by Number Register PDM-06 / MUKID / 0118 on behalf of Defendant I Astar Hendi Called Kuncung Bin Jumana and Defendant II Adika Nopi Hadiyanto Called Usrit Bin Muh Suhadi were charged with violating the First Article 112 paragraph (1) of the Law of the Republic of Indonesia Number 35 Of 2009 on Narcotics in conjunction with Article 55 paragraph (1) to 1 of the Criminal Code or the Second Article 127 paragraph (1) letter a Law of the Republic of Indonesia Number 35 Of 2009 on Narcotics jo Article 55 paragraph (1) 1st Criminal Code.

The case his position is that the first defendant Astar Hendi Called Kuncung Bin Jumana along with Defendant II Adika Nopi Hadiyanto Called Usrit Bin Muh Suhadi on Monday, November 20, 2017 held in the ironing room house Defendant II Adika Nopi Hadiyanto Called Usrit Bin Muh Suhadi address at Dusun Karang Wetan Rt / Rw: 002/001 Village Pucang Secang District of Magelang Regency has committed the crime of "together Abusing Narcotics Group I For Yourself", which is done by using a reckoning shabu (bong) made of plastic bottles which contains clear aqua water made by Defendant II Adika Nopi Hadiyanto called Usrit Bin Muh Suhadi, by means of a plastic bottle which brand of aqua is a hole 2 (two) and given straw on each hole, then one of the straw was given a glass pipette,then after finished glass pipette is filled with meth by Defendant II Adika Nopi Hadiyanto Called Usrit Bin Muh Suhadi, then a glass pipette containing shabu Defendant II Astar Hendi Called Kuncung Bin Jumana fuels, gas lighters and then one straw Defendant I Astar Hendi Called Jumana Bin Kuncung

\footnotetext{
${ }^{9}$ Cholid Narbuko dan Abu Achmadi 2001 Metodologi Penelitian Bumi Aksara Jakarta p. 81.

${ }^{10}$ H.B. Sutopo 1998 Metodologi Penelitian Hukum Kualitatif Bagian II UNS Press Surakarta p. 37.
} 
reckoning interchangeably with defendant II Adika Nopi Hadiyanto Usrit Called Bin Muh Suhadi to methamphetamine in a glass pipette burned out.then a glass pipette containing shabu Defendant II Astar Hendi Called Kuncung Bin Jumana fuels, gas lighters and then one straw Defendant I Astar Hendi Called Kuncung Bin Jumana reckoning interchangeably with defendant II Adika Nopi Hadiyanto Called Usrit Bin Muh Suhadi until shabu inside burned down a glass pipette. Then a glass pipette containing shabu Defendant II Astar Hendi Called Kuncung Bin Jumana fuels, gas lighters and then one straw Defendant I Astar Hendi Called Kuncung Bin Jumana reckoning interchangeably with defendant II Adika Nopi Hadiyanto Called Usrit Bin Muh Suhadi until shabu inside burned down a glass pipette. ${ }^{11}$

Whereas procedures for prosecution of the case on behalf of the first defendant Astar Kuncung Called Bin Hendi Jumana and Defendant II Adika Nopi Hadiyanto Usrit Called Bin Muh Suhadi include:

- Phase Pre Prosecution

The role of the public prosecutor at the pre prosecution include:

- Receiving Notice of Commencement of Investigation (SPDP) of investigators of Police Magelang No. B / 26 / XI / 2017 / Res Drugs November 24, 2017, followed by the appointment of the Public Prosecutor to follow the development of the investigation of criminal case (P-16) Number: PRINT-1962 / 0.3 .44 / Euh.1 / 11/2017 dated 28 November 2017;

- Monitor the development of the investigation; and

- Receive the case file of the investigation (phase 1) No. B / 04 / I / 2018 / Res Mgl dated January 2, 2018, followed by a study case files. The research results of the case file is complete and competent to stand trial, then issued a notice dossier is complete (P-21) to include planned indictment (P-29), the Minutes Opinions ( $\mathrm{P}$ 24), Matrix ( $P-7)$, the Minutes of exposure of the case, and the case exposes the attendance list.

- phase Prosecution

The role of the public prosecutor at the prosecution stage covers:

- Accepting responsibility surrender the accused and the evidence of police investigation to the Prosecutor No. B / 180 / I / 2018 / Res Mgl dated January 16, 2018 , followed by the appointment of the public prosecutor to prosecute or prosecute the case in court (P-16.a ) Number: PRINT-99 / 0.3.44 / Euh.2 / 01/2018 dated January 16, 2018;

- Conducting research and rechecked against the accused and the evidence by interviewing and checking the condition of the evidence (BA-4 and BA-18), then when the defendant carried out the detention then the detention period can be extended by the public prosecutor for a 20-day (T-7 ) Number: PRINT-102 / 0.3.44 / Euh.2 / 01/2018 dated January 16, 2018;

- Bestow the following case file of evidence to the District Court for trial soon; and

${ }^{11}$ Prosecution Case File Number Register: PDM-06 / MUKID / 0118 dated January 162018. 
- Confronts the accused, the evidence and the evidence in the trial.

The trial phase of criminal case of drug abuse in the name of the first defendant Astar Kuncung Called Bin Hendi Jumana and the defendant II Adika Nopi Hadiyanto Usrit Called Bin Muh Suhadi include:

- The reading of the indictment by the public prosecutor on Monday, January 29, 2018;

- Conduct an examination of the witnesses, a letter, the defendant and show evidence in court (evidence) on Monday, February 5, 2018 and Monday, February 12, 2018;

- The reading of the warrant (P-42) by the public prosecutor on Monday, February 19, 2018 Case Registration Number: PDM-06 / MUKID / 0118 by amar demands, namely: 1) Declare the defendant Astar Hendi Called tuft Bin Jumana and defendant Adika Nopi Hadiyanto Called Usrit Bin Muh Suhadi proven legally and convincingly guilty of committing the crime of "Together Abusing Narcotics Group I For Yourself" as stipulated and punishable under Article 127 paragraph (1) a of Act No. 35 Of 2009 on Narcotics in conjunction with Article 55 paragraph (1) to 1 of the Criminal Code Charges Second Alternative Public Prosecutor; 2) Dropping imprisonment against the defendant Astar Jumana Bin Hendi tuft Called and Called Hadiyanto Nopi Adika defendant Usrit Bin Muh Suhadi each for 1 (one) year and 1 (one) month deducted for each defendant in custody while.

After the Prosecution completed read Requisitor, then each defendant a plea (plea) orally, which substantially each defendant stated the defendant regretted his actions, the defendant will no longer repeat his actions, please leniency defendant and the defendant is the backbone of the family.

The reading of the decision / verdict on Monday, February 26, 2018 No. 14 / Pid.Sus / 2018 / PN Mkd dated February 26, 2018 by the ruling are: 1) ASTAR first defendant stated tuft Called Bin Hendi Jumana and Defendant II Adika Nopi Hadiyanto Called Usrit Bin Muh Suhadi mentioned above, proven legally and convincingly guilty of committing the crime of "Together Abusing Narcotics Group I For Yourself"; 2) Convict the Defendants therefore to imprisonment each for 1 (one) year;

After The judges finish reading the verdict, then each defendant states accept the decision, as did the Public Prosecutor states accept the decision.

Therefore each party has received a verdict, so that the decision has been permanent legal power and the public prosecutor immediately executed.

- Execution phase

The role of the public prosecutor at the stage execution that is executing the defendant by putting the accused to Penitentiary Magelang based Warrant Execution Court Judgment (P-48) Number: PRINT-495 / 0.3.44 / Euh.3 / 03/2018 dated March 5, 2018 to make an official report Implementation of the Decision judge (BA-17). 


\subsection{The role of the Public Prosecutor in Implementing Crime Prosecution Against Perpetrators of Abuse of Narcotics}

The role of the Prosecutor as a subsystem of the criminal justice system contained in the legislation in force at this time either in the Code of Criminal Procedure and the Law of the Republic of Indonesia Number 16 of 2004 on the Prosecutor of the Republic of Indonesia, which acts as an investigator and serves as public prosecutor. As related to the handling of narcotics criminal case, prosecutors in this case the State Attorney Magelang act as public prosecutor.

In many parts of the world, the Prosecution has a strategic function within the criminal justice system. International recognition of the importance of the role of the public prosecutor has been manifested through The Guidelines On The Role Of Prosecutors at The 8 IN Congress on The Prevention Of Crime and the Treatment of Offenders in Havana Cuba in 1991. Therefore, in the midst of Indonesian efforts to build the criminal justice system more effective and humane, and institutional strengthening of the Prosecutor's functions is a necessity. ${ }^{12}$

The Prosecutor, in the Criminal Justice System in Indonesia has a very strategic role in the law enforcement process to achieve legal justice. Which oneJustice system criminal issystem created to address the problems of crime that could disturb public order and threaten the security of society, is a community effort to control the crimes that are within the boundaries of acceptable tolerances. ${ }^{13}$

\subsection{Factors Inhibiting Prosecution Role in Implementing the Prosecution of Perpetrators Crime Against Narcotics Abuse and How to Handle Effort}

It must be recognized that this form of crime has evolved very rapidly even transcend barriers of jurisdiction, because the eradication of crime or a crime, especially the crime of drug abuse can not simply rely on conventional and partial manner. Limitation of state, legal system differences and bureaucratic procedures should not be a hindrance to law enforcement that seemed left one step behind criminals.

That in practice in the implementation of prosecution of perpetrators of criminal acts of drug abuse in the State Attorney Magelang there are inhibiting factors that the dossier is incomplete, the type of drug is not on the list of narcotics, modus operandi that are more varied, and the calling of witnesses when the inspection process in court.

That effort Prosecution to overcome the inhibiting factors mentioned above, namely holding the sharing of information among law enforcement and related agencies, conduct legal counseling regarding the crime of abuse of narcotics, cooperation with

\footnotetext{
${ }^{12}$ RM Surachman dan Jan S. Maringka 2015 Peran Jaksa Dalam Sistem Peradilan Pidana di Kawasan Asia Pasifik Sinar Grafika Jakarta p. v.

${ }^{13}$ Mardjono Reksodiputro 1997 Kriminiologi dan Sistem Peradilan Pidana Lembaga Kriminologi UI Jakarta p. 140.
} 
the firm expedition, attended a special training Crime Narcotics and programs Attorney to to school.

\section{Closing}

\subsection{Conclusion}

Based on the results of research and discussion can be concluded as follows:

- Procedure criminal prosecution of drug abuse that includes the pre-stage of prosecution, the prosecution stage and the execution stage.

- The role of the public prosecutor in the implementation of the criminal prosecution of drug abuse that is acting as the Public Prosecutor.

- Factors inhibiting the role of the public prosecutor in the implementation of the criminal prosecution of drug abuse that is not yet complete case file, the type of narcotic drugs have not been included in the list, the modus operandi of an increasingly varied and calling witnesses when the inspection process in court. While the effort to overcome the inhibiting factor that is holding the sharing of information among law enforcement and related agencies, conduct legal counseling regarding the crime of abuse of narcotics, cooperation with expedition company, attended a special training program Crime and Narcotics Prosecutor for School.

\subsection{Suggestion}

Based on the conclusion, the author gives suggestions as follows:

- To the Government, is expected to revise Act No. 35 of 2009 on narcotics by providing authority to the Prosecutor can act as an investigator;

- To the Public Prosecutor, is expected in the prosecution handling the criminal case of drug abuse able to sue the defendant with the highest demands in accordance with the applicable law; and

- To the public, are expected to know and understand the forms of the narcotic crime, how the negative effects of drug abuse.

\section{Bibliography}

[1] Cholid Narbuko dan Abu Achmadi 2001 Metodologi Penelitian Bumi Aksara Jakarta.

[2] Dyah Ochtorina Susanti dan A'an Efendi 2014 Penelitian Hukum (Legal Research) Sinar Grafika Jakarta.

[3] Erwin Mappaseng 2009 Pemberantasan dan Pencegahan Narkoba yang Dilakukan oleh Polri dalam Aspek Hukum dan Pelaksanaannya Buana Ilmu Surakarta.

[4] H.B. Sutopo 1998 Metodologi Penelitian Hukum Kualitatif Bagian II UNS Press Surakarta. 
[5] Mardjono Reksodiputro 1997 Kriminiologi dan Sistem Peradilan Pidana Lembaga Kriminologi UI Jakarta.

[6] RM Surachman dan Jan S. Maringka 2015 Peran Jaksa Dalam Sistem Peradilan Pidana di Kawasan Asia Pasifik Sinar Grafika Jakarta.

[7] Constitution of the Republic of Indonesia Of 1945.

[8] Law of the Republic of Indonesia Number 8 of 1981 on Criminal Proceedings.

[9] Law of the Republic of Indonesia Number 16 of 2004 on the Prosecutor of the Republic of Indonesia.

[10] Law of the Republic of Indonesia Number 35 Of 2009 on Narcotics.

[11] Prosecution Case File Number Register: PDM-06 / MUKID / 0118 dated January 162018.

[12] Data Case Narcotics Crime in 2016 and 2017 in Magelang District Magelang District Attorney March 192018.

[13] Results of interviews with Adhing Tedhalosa SH (Public Prosecutor at the State Attorney Magelang) on Wednesday May 30, 2018 at 12:10 pm. 